\title{
Aetiological Factors and Therapeutic Approach to the Dumping Syndrome* $\dagger$
}

\author{
M. BRUCE SULLIVAN, $\ddagger$ M.D.; BURIS R. BOSHELL,§ M.D.
}

Brit. med. F., 1964, 1, 414-416

The term "dumping" was introduced by C. L. Mix in 1922 to describe the postprandial symptom-complex seen in patients after gastric surgery. The symptoms are of gastro-intestinal and vasomotor origin with variable predominance. They develop within 30 minutes of eating and are particularly severe after the ingestion of carbohydrates. Therapy has largely been limited to dietary and fluid restrictions and postprandial recumbency. The reported incidence of this complication varies from $0.3 \%$ (Herrington et al., 1961) to $75 \%$ (Muir, 1949). The continuing evolution of gastric surgery has made study comparisons difficult; however, the size of the gastric reservoir, the size and location of the stoma, and the individual patient's susceptibility have emerged as significant aetiological factors.

A new concept of therapy was recently presented (Buse et al., 1957 ; Le Quesne et al., 1960). These authors proposed that the essential factor in the production of the dumping reaction was a defect in carbohydrate metabolism resulting in inadequate handling of a glucose load, a lag type glucose-tolerance curve, and a resultant decrease in plasma volume, usually greater than $10 \%$, which in turn produced the dumping symptoms. They supported this hypothesis by demonstrating that insulin administered before a glucose meal markedly decreased the blood-volume change and the dumping reaction. The therapeutic implications of this were noted, and the present study was evolved to substantiate the therapeutic benefit of insulin, explore the therapeutic efficacy of an oral hypoglycaemic agent, and investigate the relationship of insulin and carbohydrate metabolism in the dumping reaction.

\section{Methods and Procedures}

The 21 patients (19 males, 2 females) included in this report were selected from the wards and out-patient services of the University and Veterans Administration Hospitals, Birmingham, Alabama. Patients with severe, persistent symptoms were selected for study. Relevant clinical data are summarized in Table I. Ages varied from 34 to 68 years. Twenty patients had had subtotal gastrectomies and one patient a total gastrectomy.

Baseline studies on each patient consisted of a three-hour to five-hour oral glucose-tolerance test utilizing a 75-g. glucose load. This test was repeated with insulin or sodium tolbutamide preceding the glucose. An intravenous tolbutamide

* From the Surgical and Medical Service of the Veterans Administration Hospital and the Departments of Surgery and Medicine, Medical College of Alabama, Birmingham, Alabama.

† This investigation was supported in part by PHS Grant (A-3069 RI NIAM) from the National Institutes of Health, Department of Health, Education, and Welfare, Public Health Service. This investigation was also supported in part by a grant from the Upjohn Company.

¥ Associate Professor of Surgery, Medical College of Alabama ; Acting Chief, Surgical Service, Veterans Administration Hospital, Birmingham, Alabama.

5 Chief, Medical Service, Veterans Administration Hospital ; Associate Professor of Medicine, Medical College of Alabama, Birmingham, Alabama. tolerance test (Unger and Madison, 1958) was performed in 18 patients. Blood volume was measured concurrently during the glucose-tolerance tests in six patients, using the RISA technique; and serum insulin response was obtained in 14 patients. Glucose was determined by the Nelson (1944) modification of the Somogyi method. Serum insulin-like activity was determined by the epididymal fat pad bioassay of Martin et al. (1958).

\begin{tabular}{|c|c|c|c|c|c|c|c|c|}
\hline \multirow{2}{*}{$\begin{array}{l}\text { Case } \\
\text { No. }\end{array}$} & \multirow[b]{2}{*}{ Age and } & \multirow[b]{2}{*}{ Sex } & \multirow{2}{*}{$\begin{array}{l}\text { Months } \\
\text { Post- } \\
\text { Surgery }\end{array}$} & \multirow{2}{*}{$\begin{array}{l}\text { Onset } \\
\text { Dumping } \\
\text { Months } \\
\text { Postop. }\end{array}$} & \multicolumn{4}{|c|}{ Weight (lb.) } \\
\hline & & & & & Preop. & $\begin{array}{l}\text { Initial } \\
\text { Study }\end{array}$ & $\begin{array}{c}\text { At } 1 \\
\text { Month }\end{array}$ & $\begin{array}{l}\text { At } 3 \\
\text { Months }\end{array}$ \\
\hline $\begin{array}{r}1 \\
2 \\
3 \\
4 \\
5 \\
6 \\
7 \\
8 \\
9 \\
10 \\
11 \\
12 \\
13 \\
14 \\
15 \\
16 \\
17 \\
18 \\
19 \\
20 \\
21\end{array}$ & $\begin{array}{l}42 \\
46 \\
63 \\
52 \\
38 \\
42 \\
43 \\
67 \\
34 \\
50 \\
68 \\
68 \\
40 \\
54 \\
40 \\
40 \\
43 \\
54 \\
46 \\
56 \\
51\end{array}$ & $\begin{array}{l}M \\
F \\
M \\
M \\
M \\
M \\
M \\
M \\
M \\
M \\
M \\
M \\
\mathbf{F} \\
M \\
M \\
M \\
M \\
M \\
M \\
M \\
M\end{array}$ & $\begin{array}{r}48 \\
24 \\
48 \\
9 \\
84 \\
48 \\
4 \\
48 \\
36 \\
72 \\
60 \\
84 \\
36 \\
24 \\
18 \\
60 \\
29 \\
48 \\
48 \\
48 \\
72\end{array}$ & $\begin{array}{r}0 \\
0 \\
4 \\
8 \\
0 \\
5 \\
0 \\
0 \\
0 \\
0 \\
0 \\
0 \\
0 \\
0 \\
0 \\
54 \\
8 \\
0 \\
0 \\
0 \\
0\end{array}$ & $\begin{array}{l}155 \\
118 \\
138 \\
140 \\
218 \\
140 \\
147 \\
140 \\
168 \\
145 \\
100 \\
118 \\
104 \\
138 \\
165 \\
205 \\
145 \\
162 \\
165 \\
130 \\
172\end{array}$ & $\begin{array}{l}118 \\
107 \\
117 \\
113 \\
147 \\
120 \\
119 \\
129 \\
120 \\
114 \\
104 \\
121 \\
95 \\
111 \\
140 \\
149 \\
136 \\
123 \\
123 \\
119 \\
132\end{array}$ & $\begin{array}{l}121 \frac{1}{2} \\
105 \frac{1}{2} \\
122 \frac{1}{4} \\
114 \\
150 \\
129 \\
123 \\
128 \\
118 \\
102 \\
124 \frac{1}{2} \\
116 \\
140 \\
152 \\
138 \frac{1}{2} \\
1249 \\
130 \\
124 \\
133\end{array}$ & $\begin{array}{l}104 \\
128 \\
117 \\
143 \\
154 \\
142 \frac{1}{2} \\
126 \\
136 \\
127 \\
138\end{array}$ \\
\hline
\end{tabular}

$1 \mathrm{~kg} .=2 \cdot 2 \mathrm{lb}$.

Chronic studies to determine the long-term effectiveness of an oral hypoglycaemic agent, sodium tolbutamide, were undertaken with 19 of the 21 patients. Sodium tolbutamide was selected because of its rapid absorption and effect, thus being peculiarly suited to the dietary programme. Dosage requirements varied from 0.25 to $1 \mathrm{~g}$., administered 10 to 30 minutes before meals, depending on the individual responsiveness as determined by preliminary testing.

After an effective programme was established, 10 of the patients were subjected to a double-blind study. Two unknown preparations were divided into bottles Nos. 1, 2, 3, and 4 . These were alternated at weekly intervals, and the clinical response was noted (see Table II).

TABLE II.-Results of Double-blind Study

\begin{tabular}{|c|c|c|c|c|}
\hline Case No. & No. $1^{*}$ & No. $2 \dagger$ & No. $3 \dagger$ & No. 4* \\
\hline \multirow{7}{*}{$\begin{array}{r}1 \\
2 \\
3 \\
4 \\
6 \\
7 \\
17 \\
18 \\
19 \\
21\end{array}$} & + & - & - & \pm \\
\hline & $\bar{t}$ & $\bar{z}$ & \pm & + \\
\hline & + & $\bar{z}$ & $\bar{z}$ & $\stackrel{+}{+}$ \\
\hline & + & - & + & - \\
\hline & + & $\bar{z}$ & $\bar{z}$ & $\stackrel{ \pm}{+}$ \\
\hline & $\stackrel{+}{+}$ & $\bar{z}$ & $\bar{z}$ & $\bar{t}$ \\
\hline & $9 / 10$ & $0 / 10$ & $2 / 10$ & $7 / 10$ \\
\hline
\end{tabular}

* No. 1 and No. 4 (35-T... Sodium tolbutamide).

$\dagger$ No. 2 and No. 3 (34-T... Placebo).

Beneficial response recorded as + . No benefit noted recorded as -. Equivocal response noted recorded as \pm . 


\section{Results}

The blood-glucose peak occurred within one hour of the oral glucose load in all patients. The average peak level was 227 mg./100 ml., with variations from 144 to $318 \mathrm{mg} . / 100 \mathrm{ml}$. Tolbutamide or insulin given prior to the glucose load depressed the peak by 6 to $54 \%$. The effects of tolbutamide and insulin were comparable. An example of the clinical response during the glucose-tolerance tests is depicted in the Chart. Thirteen of 19 patients were either frankly diabetic or diabetic suspects as determined by the intravenous tolbutamide test (Unger and Madison, 1958) (see Table III).

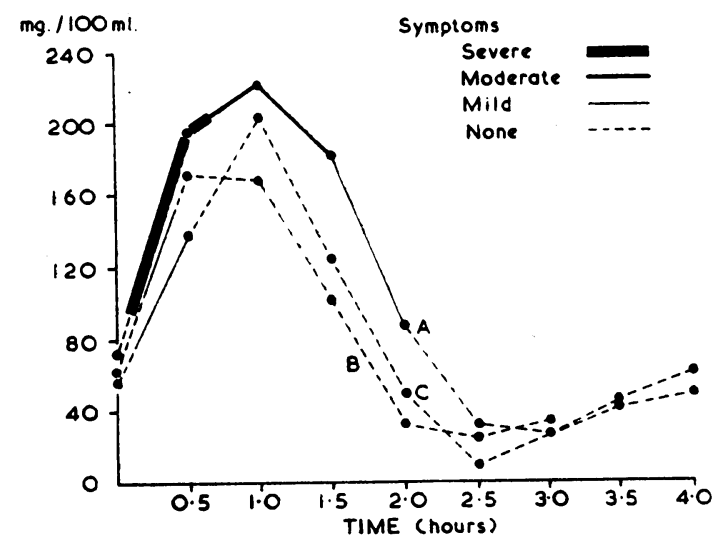

Case 9. Glucose-tolerance responses. $A=75$ g. glucose. $B=15$ units insulin 40 minutes before $75 \mathrm{~g}$. glucose. $C=$ $1 \mathrm{~g}$. tolbutamide sodium 30 minutes before $75 \mathrm{~g}$. glucose.

TABLE III.-Blood-glucose Levels after Intravenous Tolbutamide

\begin{tabular}{|c|c|c|c|c|c|}
\hline \multirow{3}{*}{$\begin{array}{l}\text { Case } \\
\text { No. }\end{array}$} & \multicolumn{5}{|c|}{ Blood Sugar } \\
\hline & \multirow{2}{*}{$\underset{\mathrm{Mg} . / 100 \mathrm{ml} .}{\text { Fasting }}$} & \multicolumn{2}{|c|}{ At 20 Minutes } & \multicolumn{2}{|c|}{ At 30 Minutes } \\
\hline & & $\mathrm{Mg} . / 100 \mathrm{ml}$ & $\%$ of F.B.S. & Mg. $/ 100 \mathrm{ml}$. & $\%$ of F.B.S. \\
\hline $\begin{array}{r}1 \\
2 \\
3 \\
4 \\
5 \\
6 \\
7 \\
8 \\
10 \\
11 \\
12 \\
13 \\
14 \\
15 \\
16 \\
17 \\
18 \\
19 \\
21\end{array}$ & $\begin{array}{l}56 \\
89 \\
77 \\
66 \\
73 \\
88 \\
82 \\
64 \\
74 \\
96 \\
79 \\
84 \\
90 \\
77 \\
85 \\
72 \\
78 \\
75 \\
89\end{array}$ & $\begin{array}{l}52 \\
79 \\
78 \\
46 \\
51 \\
66 \\
57 \\
61 \\
80 \\
52 \\
47 \\
75 \\
34 \\
59 \\
70 \\
69 \\
75\end{array}$ & $\begin{array}{r}93 \\
89 \\
101 \\
70 \\
69 \\
75 \\
\\
89 \\
89 \\
83 \\
66 \\
55 \\
83 \\
40 \\
82 \\
90 \\
92 \\
84\end{array}$ & $\begin{array}{r}46 \\
72 \\
63 \\
40 \\
42 \\
62 \\
73 \\
79 \\
49 \\
54 \\
73 \\
52 \\
38 \\
66 \\
58 \\
26 \\
53 \\
49 \\
57 \\
69\end{array}$ & $\begin{array}{l}82 \\
81 \\
82 \\
62 \\
57 \\
70 \\
89 \\
76 \\
73 \\
76 \\
66 \\
52 \\
73 \\
75 \\
31 \\
74 \\
63 \\
76 \\
77\end{array}$ \\
\hline
\end{tabular}

Table IV compares the blood-glucose elevations after glucose ingestion with and without tolbutamide administration. Tolbutamide usually decreased the blood-sugar elevation at one-half hour as well as the peak rise. Often the peak rise in

TABLE IV.-Comparison of Blood-Glucose Elevation after Glucose Load

\begin{tabular}{|c|c|c|c|c|}
\hline \multirow{2}{*}{$\begin{array}{l}\text { Case } \\
\text { No. }\end{array}$} & \multicolumn{2}{|c|}{$\%$ of F.B.S. at 1 Hour } & \multicolumn{2}{|c|}{$\%$ of F.B.S. at Peak Rise } \\
\hline & Without Tolb. & With Tolb. & Without Tolb. & With Tolb. \\
\hline $\begin{array}{r}3 \\
4 \\
5 \\
6 \\
8 \\
13 \\
16\end{array}$ & $\begin{array}{l}280 \\
320 \\
250 \\
230 \\
210 \\
169 \\
208\end{array}$ & $\begin{array}{l}280 \\
286 \\
210 \\
220 \\
310 \\
173\end{array}$ & $\begin{array}{l}308 \\
320 \\
250 \\
277 \\
324 \\
169 \\
208\end{array}$ & $\begin{array}{l}309 \\
286 \\
210 \\
251 \\
310 \\
173\end{array}$ \\
\hline 7 & 236 & 200 & 236 & 200 \\
\hline
\end{tabular}

blood-glucose level was already present at the time of the halfhour sampling.

The serum insulin-like activity (I.L.A.) response during the oral-glucose-tolerance tests is shown in Table V. The mean I.L.A. response was $244 \mathrm{micro}-$ units $/ \mathrm{ml}$. in the fasting state,
$375 \mu \mathrm{u} . / \mathrm{ml}$. at half-hour, $412 \mu \mathrm{u} . / \mathrm{ml}$. at one hour, and 405 $\mu \mathrm{u} . / \mathrm{ml}$. at two hours during the standard oral-glucose-tolerance test. When tolbutamide was administered prior to the glucose the mean respective values were $257,401,492$, and $439 \mu \mathrm{u}$./ $\mathrm{ml}$. respectively. Although not significantly different the rise in I.L.A. was slightly greater when the glucose-tolerance test was preceded by sodium tolbutamide administration. In both cases, however, the I.L.A. response is of the type usually seen in the patient with adult onset type diabetes mellitus (Berson et at., 1961).

\begin{tabular}{|c|c|c|c|c|c|c|c|c|}
\hline \multirow{2}{*}{$\begin{array}{l}\text { Case } \\
\text { No. }\end{array}$} & \multicolumn{4}{|c|}{ 75-g. Glucose Load } & \multicolumn{4}{|c|}{ Tolbutamide +75-g. Glucose Load } \\
\hline & Fasting & $\frac{1}{2}$ Hour & 1 Hour & 2 Hour & Fasting & $\frac{1}{2}$ Hour & 1 Hour & 2 Hour \\
\hline \multirow{10}{*}{$\begin{array}{c}1 \\
2 \\
3 \\
4 \\
5 \\
8 \\
10 \\
11 \\
12 \\
13 \\
15 \\
16 \\
17 \\
18 \\
20 \\
21\end{array}$} & $\begin{array}{l}93 \\
949\end{array}$ & $\begin{array}{l}245 \\
572\end{array}$ & $\begin{array}{r}428 \\
1,005\end{array}$ & $\begin{array}{l}148 \\
546\end{array}$ & \multirow{3}{*}{$\begin{array}{r}80 \\
243\end{array}$} & \multirow{3}{*}{$\begin{array}{l}260 \\
660\end{array}$} & \multirow{3}{*}{$\begin{array}{r}298 \\
1,134\end{array}$} & \multirow{3}{*}{$\begin{array}{r}215 \\
1,282\end{array}$} \\
\hline & $\begin{array}{l}714 \\
158\end{array}$ & $\begin{array}{l}211 \\
166\end{array}$ & $\begin{array}{r}285 \\
182\end{array}$ & $\begin{array}{l}111 \\
160\end{array}$ & & & & \\
\hline & 198 & & & & & & & \\
\hline & 161 & 478 & 446 & 210 & & & & \\
\hline & 160 & 359 & $\begin{array}{l}492 \\
315\end{array}$ & 435 & 231 & $\begin{array}{l}301 \\
452\end{array}$ & 357 & 210 \\
\hline & 203 & 440 & 465 & 190 & 58 & 284 & $\begin{array}{l}479 \\
165\end{array}$ & 133 \\
\hline & $\begin{array}{l}417 \\
148\end{array}$ & $\begin{array}{l}649 \\
255\end{array}$ & $\begin{array}{l}562 \\
220\end{array}$ & 273 & 182 & 410 & 212 & 187 \\
\hline & & 404 & 621 & 458 & & 662 & 649 & 737 \\
\hline & 235 & 380 & 172 & 416 & 297 & 384 & 864 & 274 \\
\hline & 24 & 374 & 412 & 405 & 257 & 401 & 492 & 439 \\
\hline
\end{tabular}

Of the 21 patients, 19 noted subjective improvement sufficient to warrant a prolonged trial of therapy. Four of these patients subsequently failed to maintain an adequate response to warrant continued therapy and were deleted from the study. Treatment of two other patients was discontinued because of alcoholism.' The remaining 13 patients continued to improve throughout the study period, which has been as long as two and a half years and in no case less than three months. An interesting phenomenon was shown by three patients who had a complete remission of symptoms. Two of these relapsed within a few months and again required tolbutamide, but one patient remained symptom-free for more than 15 months.

The average gain in weight during the first month of therapy for 19 patients was $3.3 \mathrm{lb}$. (1.5 kg.). The average weight gain for 15 patients treated over a period of three months was $5.2 \mathrm{lb}$. $(2.4 \mathrm{~kg}$.). However, weight gain tended to plateau after several months of therapy. Only four negative responses to tolbutamide were noted during the double-blind study (Table II), and only two placebo responses were observed.

There were no complications from drug therapy. However, approximately one-third of the patients did complain of epigastric burning between the time of ingestion of the tablet and their meal. This was controlled by having the patient take the tablet with a small amount of sodium bicarbonate or food. The only other reaction noted was a hypoglycaemic reaction one and a half to two hours after meals. This was readily controlled by having the patient eat or drink something an hour and a half after his meal. This reaction decreased rapidly as the patients increased their dietary intake.

\section{Discussion}

The observations of Hobsley (1960) and of Le Quesne et al. (1960) that insulin decreased dumping symptoms after a glucose meal were readily confirmed in this study. These authors postulated that the effect of insulin was to enhance glucose utilization, which would secondarily decrease the amount of fluid lost into the gastro-intestinal tract by causing a more rapid absorption of glucose, thereby decreasing the osmotic pull of fluid into the intestinal lumen. The enhanced absorption is presumably a secondary effect, since insulin has not

${ }^{1}$ It was noted that the benefits of sodium tolbutamide were completely negated by the ingestion of alcohol. 
been demonstrated to have a primary action on absorption from the gastro-intestinal tract.

Sodium tolbutamide is rapidly absorbed and stimulates the release of endogenous insulin from the beta cells of the pancreas ; thus it is not surprising that this agent would have an effect similar to that of insulin in preventing the dumping symptoms.

An abnormal intravenous tolbutamide-tolerance test in 12 out of 18 of the patients studied suggests a basic impairment of carbohydrate tolerance and perhaps of insulin reserve. Since there is no evidence that peptic ulcers are unusually common in patients with diabetes mellitus it would be rather surprising to find typical diabetes mellitus in patients with a subtotal gastrectomy unless the operation itself has a diabetogenic effect. The repeated stimulation of the beta cells by the extreme hyperglycaemic peak that occurs each time after the ingestion of food could possibly eventually exhaust the insulin reserve.

Beta-cell exhaustion secondary to prolonged stimulation is not without precedent (Ingle, 1956 ; Buse et al., 1957). Of course complete exhaustion is not present in these patients since they are not overtly diabetic. The sluggish insulin release and abnormal response to intravenous sodium tolbutamide is similar to that seen in the patient with adult-onset type of diabetes mellitus. These factors could help explain the lag-type glucosetolerance test and presumed decreased peripheral glucose uptake noted by Hobsley and Le Quesne (1960). The poor state of nutrition seen in many of the patients with dumping may in part account for the abnormal carbohydrate tolerance. The delayed onset of dumping symptoms in five of these patients from 4 to 54 months after operation is consistent with the beta-cell-exhaustion theory.

The ability to demonstrate effectiveness of the sodium tolbutamide in a double-blind study confirms our initial impression that the response to tolbutamide is real and not a placebo effect.

We have not confirmed the shifts in plasma volume noted by Le Quesne et al. (1960); however, this effect has been noted by others and, on a purely theoretical basis, should occur. The failure of measurable shifts of plasma volume to occur in all patients with dumping is not surprising and probably represents inadequacy of techniques in some cases and further suggests that the aetiology of dumping is multifactorial.

The observations of Johnson and Jesseph (1961) that serotonin antagonists prevent dumping is of interest and suggests that the effect of insulin and of tolbutamide on serotonin metabolism might be profitably explored.
In the evaluation of any therapy for dumping, it is mandatory first to identify clearly the dumping symptomatology from the numerous post-gastrectomy "syndromes." It must be added that many patients have two or more of these symptomproducing complications, and for effective patient-control each component must be identified and treated.

\section{Summary}

Insulin has been noted by Hobsley and Le Quesne to decrease the "dumping" symptoms in a significant percentage of patients studied.

The results of the present study confirm those of Hobsley and Le Quesne and further demonstrate that oral sodium tolbutamide is as effective as insulin. Not only was a lag-type glucosetolerance test demonstrated in these patients but a "diabetic type" response to intravenous tolbutamide and a sluggish release of insulin-like activity similar to that seen in the diabetic patient was noted.

The possibility that a subtotal gastrectomy is diabetogenic and the possible mechanisms of the action of insulin and tolbutamide are discussed.

We wish to thank Dr. Champ Lyons, Professor and Chairman, Department of Surgery, Medical College of Alabama, for his invaluable assistance in suggesting this study and his advice throughout the study; and Dr. James A. Pittman, Chief of the Radioisotope Service at the Birmingham Veterans Administration Hospital, and his staff for their support of this study.

\section{REFERENCES}

Berson, S. A., and Yalow, Rosalyn S. (1961). Amer. f. Med., 31, 874.

Buse, J., Gundersen, K., and Lukens, F. D. W. (1957). Diabetes, 6,428 .

Herrington, J. L., jun., Edwards, W. H., and Edwards, L. W. (1961). Surgery, 49, 540.

Hobsley, M., and Le Quesne, L. P. (1960). Brit. med. F., 1, 147.

Ingle, D. J. (1956). Diabetes, 5, 187.

Johnson, L. P., and Jesseph, J. E. (1961). Surg. Forum, 12, 316.

Le Quesne, L. P., Hobsley, M., and Hand, B. H. (1960). Brit. med. J., 1, 141 .

Martin, D. B., Renold, A .E., and Dagenais, Y. M. (1958). Lancet, 2, 76

Mix, C. L. (1922). Surg. Clin. N. Amer., 2, 617.

Muir, A. (1949). Brit. f. Surg., 37, 165.

Nelson, N. (1944). 7. biol. Chem., 153, 375.

Seltzer, H. S., and Smith, W. L. (1959). Diabetes, 8, 417.

Unger, R. H., and Madison, L. L. (1958). Ibid., 7, 455. 